\title{
PENGARUH VARIASI BENTUK DAN UKURAN PONTON TERHADAP KETINGGIAN AIR
}

Rotua Bebrianita Palentina ${ }^{1}$, Muhammad Rif' $a^{2}{ }^{2}$, Massus Subekti ${ }^{3}$,

${ }^{1,2.3 .}$ Pendidikan Teknik Elektro, Fakultas Teknik, Universitas Negeri Jakarta

${ }^{1}$ Email : bebri_geheimnisvoll@yahoo.com

\begin{abstract}
.
This study aims to determine the influence of the shape and size of the buoy to the height of the air.The research method used is the method of development. Development of PLTA-GL.By changing the shape of the buoy with 3 variations of form, ie: kubu, tube, and ball but the volume size is fixed and by changing the size of buoy with 3 variationd size of from; $0,1 \mathrm{~m}^{3}, 0,125 \mathrm{~m}^{3}$, dan $0,15 \mathrm{~m}^{3}$ but the shape is fixed.

From the research results obtained that the highest water level on the buoy ball with $0,15 \mathrm{~m}^{3}$ whit water height of 28,1575251 meters and the lowest water level is on the buoy shaped cubes with volume 0,1 $\mathrm{m}^{3}$ with water level of 14,01078389 meters
\end{abstract}

Keywords: Size Ponton, Shape of ponton,water level

\begin{abstract}
Abstrak
Penelitian ini bertujuan untuk mengetahui pengaruh bentuk dan ukuran ponton terhadap ketinggian air. Metode penelitian yang digunakan merupakan metode Pengembangan. Pengembangan dilakukan Pada Pembangkit Tenaga Air-Laut (PLTA-GL). Dengan mengubah-ubah bentuk ponton dengan 3 variasi bentuk yaitu, kubus, tabung, dan bola namun ukuran volume tetap dan dengan mengubah-ubah variasi ukuran volume ponton ke dalam 3 variasi yaitu; $0,1 \mathrm{~m}^{3}, 0,125 \mathrm{~m}^{3}$, dan $0,15 \mathrm{~m}^{3}$ namun bentuk tetap.

Dari hasil penelitian di dapatkan bahwa ketinggian air tertinggi pada ponton bola dengan volume $0,15 \mathrm{~m}^{3}$ dengan ketinggian air sebesar 28,1575251 meter, dan ketinggian air terendah terdapat pada ponton kubus dengan volume $0,1 \mathrm{~m}^{3}$ dengan ketinggian air sebesar 14,01078389 meter.
\end{abstract}

Kata Kunci : Ukuran Ponton, Bentuk Ponton, Ketinggian Air

\section{PENDAHULUAN}

Menurut Badan Pusat statistik, jumlah penduduk Indonesia pada tahun 1920, 1961, 1971, 1980,1990, 2000, 2010 berturut-turut ialah 60,7 juta jiwa; 97,1 juta jiwa; 119,2 juta jiwa; 146,9 juta jiwa; 178,6 juta jiwa; 205,1 juta jiwa; dan 237,6 juta jiwa. Dengan, jumlah penduduk yang besar dan terus meningkat menyebabkan permintaan konsumsi energi menjadi besar dan akan terus meningkat.

Meningkatnya kebutuhan akan energi dapat terlihat juga dari data mengenai besarnya energi yang dibutuhkan dari tahun 2004 sampai tahun 2014. Menurut Kementrian Energi Dan Sumber Daya Mineral (2016: 15), Selama periode 2004 sampai dengan 2014, konsumsi energi primer Indonesia meningkat dari 127 juta TOE (Tonnes Oil Equivalent atau setara ton minyak) menjadi 215 juta TOE (Tonnes Oil Equivalent atau setara ton minyak), atau tumbuh $5,4 \%$ per tahun. Menurut Suyitno (2011: 41) konsumsi energi dunia dari tahun 1960-1990 meningkat dari 63,5 JBMEH (jutaan barel minyak ekuivalen per hari) menjadi 173,0 JBMEH (jutaan barel minyak ekuivalen per hari). Sehingga dapat terlihat kebutuhan energi di Indonesia dan didunia yang meningkat dari waktu ke waktu.
Energi merupakan kemampuan untuk melakukan suatu kerja. energi dihasilkan dari beragam sumber energi seperti matahari, batu bara, angin, dan gas. Sumber energi adalah segala sesuatu yang mampu menghasilkan energi. Sumber energi dibagi menjadi sumber energi yang terbarukan dan sumber energi tak terbarukan.

Energi terbarukan merupakan energi yang ramah lingkungan dan lestari. Energi tak terbarukan merupakan sumber energi yang jumlahnya terbatas memiliki dampak negatif dari penggunaannya yaitu dapat mencemari lingkungan dan efek pemanasan global. Energi tak terbarukan meliputi batu bara, minyak bumi, nuklir dan gas bumi.Energi terbarukan dibagi menjadi energi matahari, energi air, energi panas bumi, energi biomassa, energi angin dan energi sumber daya laut.

Menurut Kementrian ESDM (2016:22), potensi energi gelombang laut di Indonesia cukup besar berkisar antara 10-20 kW per meter gelombang, meskipun cukup menjanjikan namun pengembangan teknologi pemanfaatkan energi gelombang laut di Indonesia saat ini masih belum optimal. Untuk mendapatkan Pembangkit Listrik Tenaga Air Gelombang Laut (PLTA-GL) yang 
optimal diperlukan penelitian yang mendalam. Penelitian yang dilakukan sebelumnya ialah mengenai pengaruh tiap unit (jumlah ponton, panjang lengan kuasa, dan diameter pompa) dengan ketinggian maksimal, debit jatuh air dan daya yang dihasilkan. Peneliti menambah dan mengurangi jumlah ponton, panjang lengan kuasa, dan diameter pompa. Setelah mendapatkan performa yang optimal, penelitian dilanjutkan dengan meneliti pengaruh ponton dan gelombang laut terhadap Pembangkit Listrik Tenaga Air Gelombang Laut (PLTA-GL) sehingga dapat menghasilkan kinerja yang optimal.

Untuk mendapatkan ponton yang optimal maka peneliti meneliti pengaruh variasi bentuk dan ukuran ponton. Di mana, Ponton merupakan suatau alat konversi tenaga gelombang laut ynag bergerak naik turun secara periodik berdasarkan gelombang laut..

\section{METODE}

Tujuan pengembangan adalah untuk mencari model ponton yang optimal untuk Pembangkit Listrik Tenaga Air Gelombang Laut (PLTAGL). Metode pengembangan adalah dengan cara merubah-ubah bentuk ponton namun volume tetap, dan merubah ukuran volume ponton namun bentuk ponton tetap. Sasaran produk adalah mendapatkan model ponton yang optimal untuk Pembangkit Listrik Tenaga Air Gelombang Laut (PLTA-GL). Bentuk ponton yang digunakan yaitu, kubus, tabung, dan bola dengan variasi ukuran volume sebesar $0,1 \mathrm{~m}^{3}$; $0,125 \mathrm{~m}^{3}$; dan $0,125 \mathrm{~m}^{3}$.

\section{Tahapan Desain Produk}

Untuk mendapatkan besaran luas permukaan kubus adalah dengan memasukkan besaran sisi kubus ke dalam fungsi kuadrat dan dimasukkan kedalam fungsi kali bersama dengan konstan yang bernilai 6 dan hasilnya akan muncul pada display. Gambar simulasi dapat dilihat pada gambar 1 sebagai berikut:

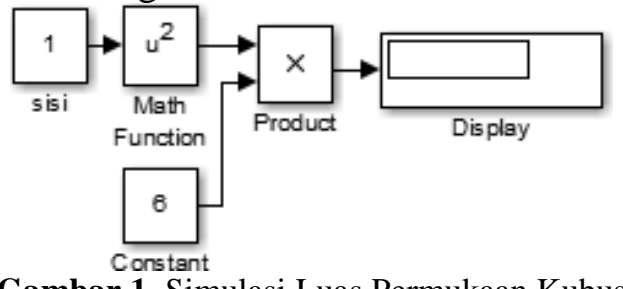

Gambar 1. Simulasi Luas Permukaan Kubus

Untuk mendapatkan besaran luas permukaan tabung adalah dengan memasukkan besaran konstanta bernilai 2, nilai phi, nilai jari-jari dan hasil penjumlahan antara jari-jari dan tinggi ke dalam fungsi kali. Hasilnya akan terlihat pada display. Gambar simulasi dapat dilihat pada gambar 2 sebagai berikut:

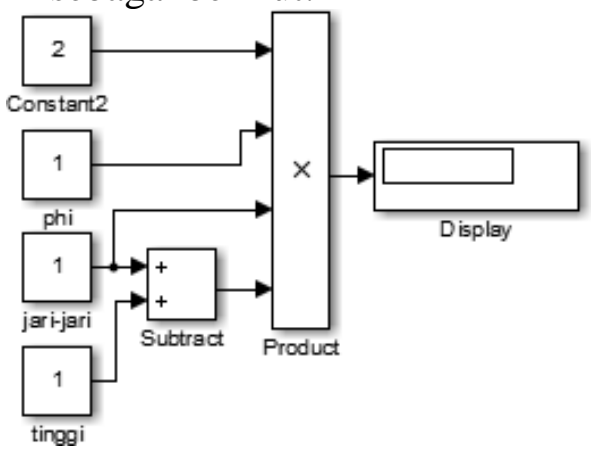

Gambar 2. Simulasi Luas Permukaan Tabung

Untuk mendapatkan besaran luas permukaan bola adalah dengan memasukkan besaran jari-jari bola ke dalam fungsi kuadrat dan dimasukkan kedalam fungsi kali bersama dengan konstan yang bernilai 4 dan besaran phi. Hasilnya dapat terlihat pada display. Gambar simulasi dapat dilihat pada gambar 3 sebagai berikut:

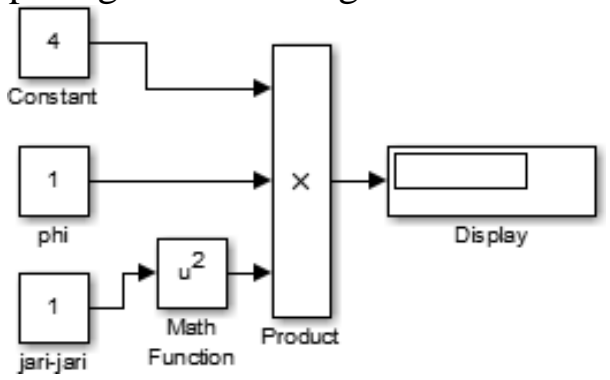

Gambar 3. Simulasi Luas Permukaan Bola

Besarnya luas permukaan ponton yang terkena laut adalah dengan memasukkan besaran nilai amplitudo dan frekuensi gelombang laut pada sine wave dan konstanta yang bernilai $2 \mathrm{ke}$ dalam fungsi tambah lalu ke fungsi kali sebesar 0,25 dan dikalikan dengan luas permukaan ponton. Hasilnya akan terlihat pada scope dalam bentuk grafik. Gambar simulasi dapat dilihat pada gambar 4 sebagai berikut:

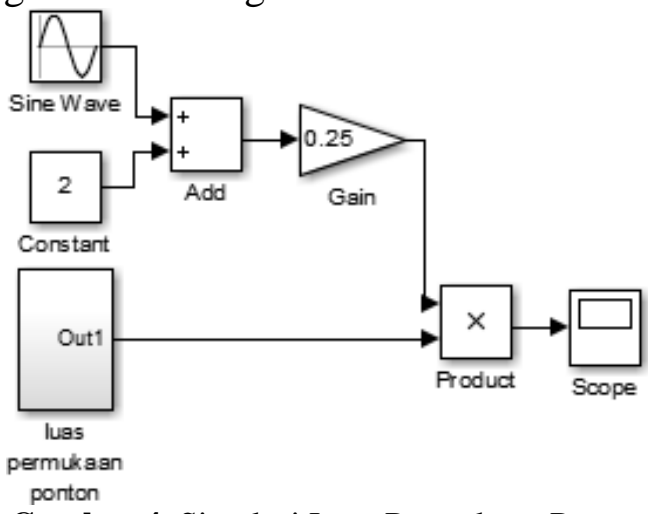

Gambar 4. Simulasi Luas Permukaan Ponton 
Untuk mendapatkan gaya pada ponton terlebih dahulu mengalikan konstanta bernilai 0,25 , massa jenis air laut, gravitasi bumi, dan luas permukaan ponton kuadrat. Hasilnya akan terlihat pada gambar 5 sebagai berikut :

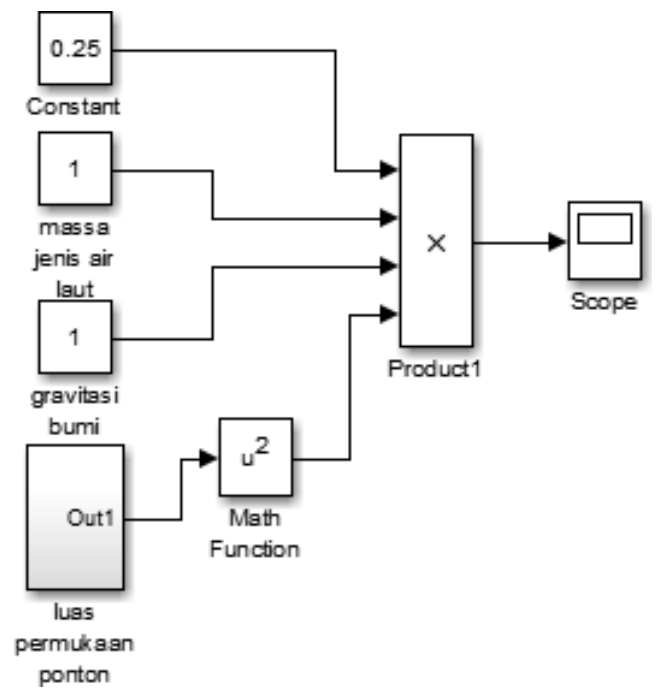

Gambar 5. Simulasi Gaya Ponton

Untuk mendapatkan besaran gaya pada pompa terlebih dahulu memasukkan besaran gaya ponton ke dalam fungsi detect decrease lalu dimasukkan ke dalam fungsi kali bersamaan dengan gaya ponton dan panjang tuas 1 lalu dimasukkan ke dalam fungsi bagi, lalu dimasukkan ke dalam fungsi bagi bersama dengan panjang tuas 2 di mana panjang tuas 2 sebagai pembagi. Hasilnya akan terlihat pada gambar 6 sebagai berikut :

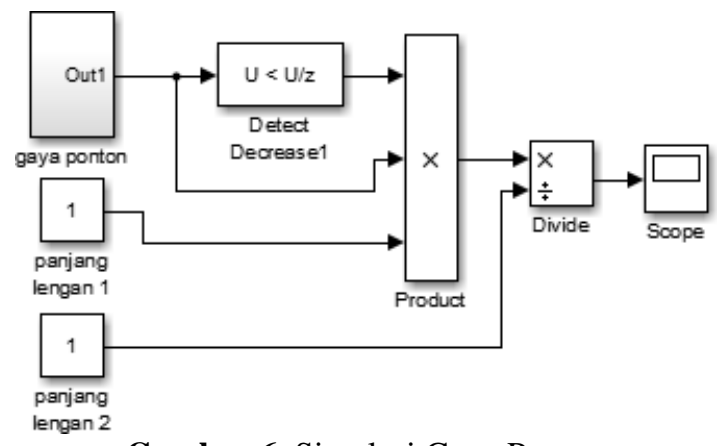

Gambar 6. Simulasi Gaya Pompa

Untuk mendapatkan besaran ketinggian air keluaran pompa dengan membagi hasil gaya ponton dengan massa jenis air laut, gaya gravitasi bumi, dan luas permukaan pompa dan hasilnya akan terlihat pada gambar 7 sebagai berikut :

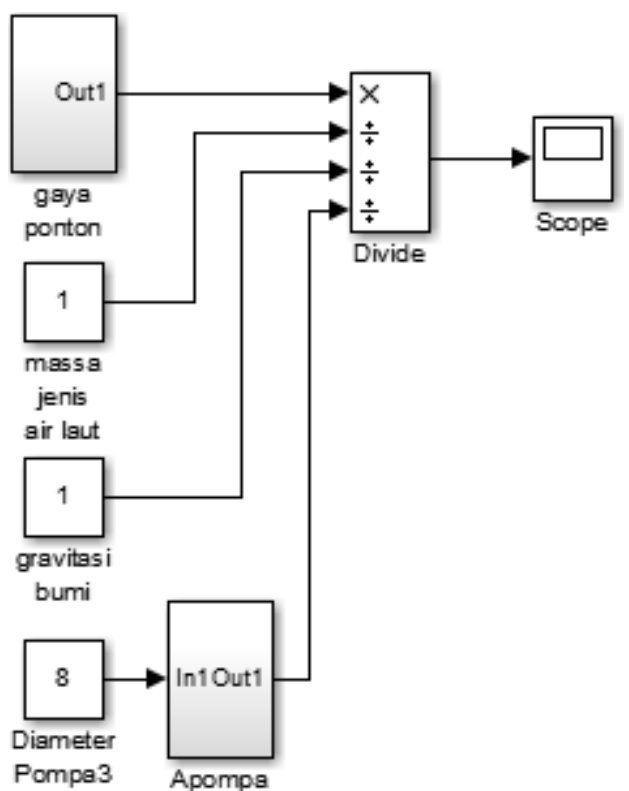

Gambar 7. Simulasi Ketinggian Air Keluaran Pompa

Untuk mendapatkan besaran luas penampang pada pompa terlebih dahulu mengubah besaran luas penampang dari satuan inchi ke dalam meter dengan cara memasukkan besaran diameter penampang pompa dan konstanta sebesar 0.0254 ke dalam fungsi kali. Setelah itu, dimasukkan ke dalam fungsi kuadrat lalu dimasukkan ke dalam fungsi kali bersama dengan nilai phi dan di bagi dengan konstanta sebesar 4 dan hasilnya akan terlihat pada display dalam bentuk bilangan atau angka sebagaimana gambar 8 sebagai berikut :

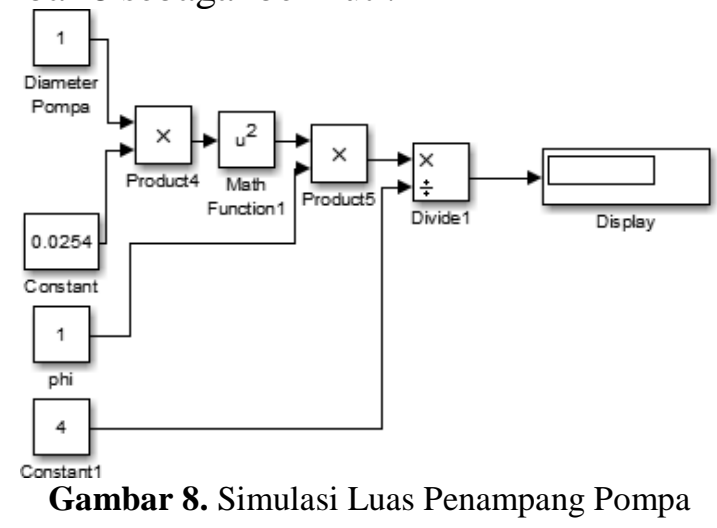

Untuk mendapatkan banyaknya volume air keluaran pompa dengan terlebih dahulu mengalikan panjang langkah dan luas permukaan pompa. Lalu dimasukkan ke fungsi delay dikurang dengan hasil perkalian panjang langkah dan luas permukaan pompa sebelumnya lalu dimasukkan ke dalam fungsi dead zone dan hasilnya akan terlihat pada scope dalam bentuk grafik sebagaimana gambar 9 sebagai berikut : 


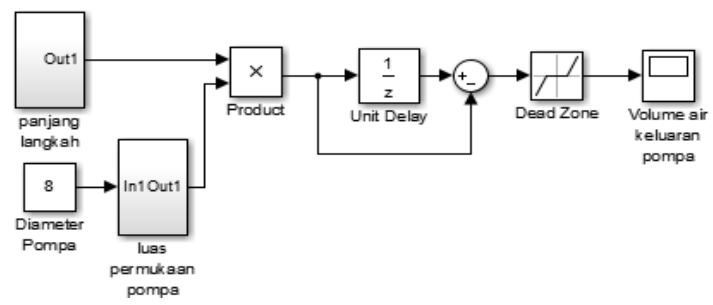

Gambar 9. Simulasi Volume Air Keluaran Pompa

Untuk mendapatkan banyaknya volume air yang ditampung di reservoir hasilnya akan terlihat pada scope dalam bentuk grafik sebagaimana gambar 10 sebagai berikut :

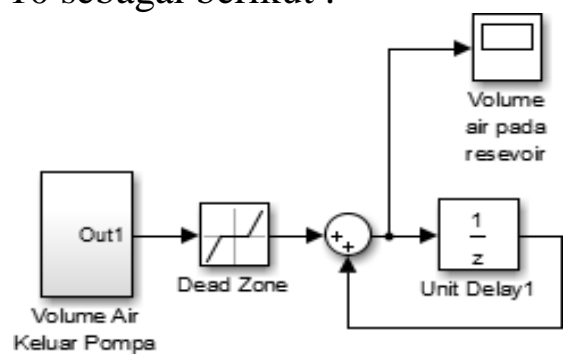

Gambar 10. Simulasi Volume Air Pada Reservoir

Untuk mendapatkan banyaknya volume air yang dibutuhkan dengan mengalikan ketinggian air keluaran pompa, gaya gravitasi bumi dan konstanta bernilai 2 dan memasukkkan ke dalam fungsi akar dua dan akan terlihat hasilnya pada scope dalam bentuk grafik sebagaimana gambar 11 sebagai berikut :

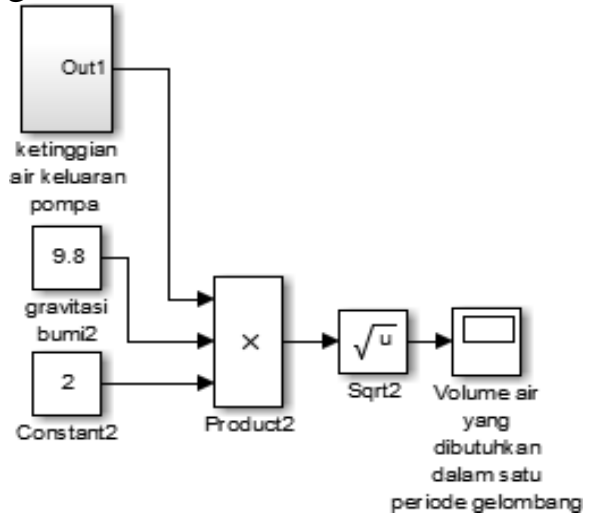

Gambar 11. Simulasi Volume Air Yang Dibutuhkana Teknik Analisis Data

Teknik analisis data yang digunakan adalah teknik komparasi/ perbandingkan. Perbandingan yang dilakukan pada hasil simulasi dari tiap-tiap ukuran dan bentuk ponton pada setiap proses sehingga didapatkan model ponton yang optimal.

\section{HASIL DAN PEMBAHASAN}

\section{Tahapan Pengembangan}

Tahapan pengembangan dilakukan dengan cara menentukan konstanta dan asumsi. konstanta yang digunakan dalam perhitungan yaitu phi $(\pi)=3,14$; massajenis air laut $(\rho)=$
$1030 \mathrm{~kg} / \mathrm{m}^{3} ; \mathrm{kg} / \mathrm{m}^{3}$ dan gravitasi bumi $(\mathrm{g})=9,8$ $\mathrm{m} / \mathrm{s}^{2}$ dan mengasumsikan gelombang laut linear dengan panjang tuas $\left(l_{2}\right)=2$ meter; panjang tuas $\left(l_{1}\right)=4$ meter; diameter pompa $\left(\mathrm{A}_{1}\right)=8 \mathrm{inchi}$; panjang langkah $=$ Amplitudo gelombang $=1$ meter; periode $(\mathrm{T})=4$ detik; dan diameter keluaran reservoir $\left(\mathrm{A}_{2}\right)=1$ inchi.

\section{Hasil Simulasi Dan Perhitungan}

Tabel 1. Hasil Simulasi dan Hitung Ketinggian Air

\begin{tabular}{crrr} 
Bentuk & $\begin{array}{c}\text { Volume } \\
\text { Ponton } \\
\left(\mathbf{m}^{\mathbf{3}}\right)\end{array}$ & \multicolumn{1}{c}{ Ketinggian $\mathbf{A}(\mathbf{H})$} & $\begin{array}{l}\text { Ketinggian } \\
\text { Air Hitung } \\
\text { (Hhitung) }\end{array}$ \\
\hline Kubus & 0,1 & 14,0108 & 14,47937747 \\
& 0,125 & 18,8917 & 19,52351387 \\
& 0,15 & 24,0308 & 24,83453612 \\
Tabung & 0,1 & 8,547542 & 4,927847356 \\
& 0,125 & 11,414978 & 6,580988073 \\
& 0,15 & 14,56351 & 8,396186595 \\
Bola & 0,1 & 16,33461 & 9,41726295 \\
& 0,125 & 21,927317 & 12,64158477 \\
\hline
\end{tabular}

Dari tabel di atas menunjukkan tabel perbandingan antara hasil simulasi ketinggian ar dan hasil perhitungan ketinggian air, di mana hasil simulasi ketinggian aitr menghasilkan besaran yang jauh dari hasil perhitungan. Dari hasil simulasi ketinggian air dan hasil perhitungan ketinggian air ponton berbentuk bola dengan volume $0,15 \mathrm{~m}^{3}$ menghasilkan ketinggian yang jauh lebih besar dibandingkan ponton berbentuk kubus pada volume $0,1 \mathrm{~m}^{3} ; 0,125 \mathrm{~m}^{3}$; dan $0,15 \mathrm{~m}^{3}$, ponton berbentuk tabung pada volume $0,1 \mathrm{~m}^{3}$; $0,125 \mathrm{~m}^{3}$; dan $0,15 \mathrm{~m}^{3}$ dan pada ponton berbentuk bola dengan volume $0,1 \mathrm{~m}^{3}$; dan $0,125 \mathrm{~m}^{3}$.

Tabel 2. Hasil Simulasi dan Hitung Volume Air Yang Keluar

\begin{tabular}{lrcr}
\hline $\begin{array}{c}\text { Bentuk } \\
\text { Ponton }\end{array}$ & $\begin{array}{c}\text { Volume } \\
\text { Ponton } \\
\left(\mathbf{m}^{\mathbf{3}}\right)\end{array}$ & $\begin{array}{c}\text { Volume Air } \\
\text { yang } \\
\text { Keluar }(\mathbf{V})\end{array}$ & $\begin{array}{c}\text { Volume Air } \\
\text { yang Keluar } \\
\text { Hitung } \\
(\text { Vhitung) }\end{array}$ \\
\hline \multirow{3}{*}{ Kubus } & 0,1 & 0,002301952 & 0,0023 \\
& 0,125 & 0,002301952 & 0,0023 \\
& 0,15 & 0,002301952 & 0,0023 \\
Tabung & 0,1 & 0,002301952 & 0,0023 \\
& 0,125 & 0,002301952 & 0,0023 \\
& 0,15 & 0,002301952 & 0,0023 \\
Bola & 0,1 & 0,002301952 & 0,0023 \\
& 0,125 & 0,002301952 & 0,0023 \\
& 0,15 & 0,002301952 & 0,0023 \\
\hline
\end{tabular}


Dari tabel di atas menunjukkan volume air yang keluar dari hasil simulasi dan hasil perhitungan dari bentuk ponton dan ukuran ponton tidak mempengaruhi besaran volume air yang keluar karena besaran volume air yang keluar tergantung pada ketinggian gelombang laut (A).

Tabel 3. Hasil Simulasi dan Hitung Volumr Air Yang Ditampung

\begin{tabular}{crcc}
\hline Bentuk & $\begin{array}{c}\text { Volume } \\
\text { Ponton } \\
\left(\mathbf{m}^{\mathbf{3}}\right)\end{array}$ & $\begin{array}{c}\text { Volume } \\
\text { Air yang } \\
\text { Ditampung } \\
(\mathbf{V})\end{array}$ & $\begin{array}{c}\text { Volume Air } \\
\text { yang } \\
\text { Ditampung } \\
\text { Hitung } \\
\text { (Vhitung) }\end{array}$ \\
\hline Kubus & 0,1 & 0,0023 & 0,0023 \\
& 0,125 & 0,0023 & 0,0023 \\
Tabung & 0,15 & 0,0023 & 0,0023 \\
& 0,1 & 0,0023 & 0,0023 \\
Bola & 0,125 & 0,0023 & 0,0023 \\
& 0,15 & 0,0023 & 0,0023 \\
& 0,1 & 0,0023 & 0,0023 \\
& 0,125 & 0,0023 & 0,0023 \\
\hline
\end{tabular}

Dari tabel di atas menunjukkan hasil simulasi dan perhitungan dari volume air yang ditampung di resevoir dari bentuk ponton dan ukuran ponton tidak mempengaruhi besaran volume air yang ditampung di reservoir. Banyaknya air yang ditampung direservoir tergantung pada banyaknya air yang keluar dari pompa.

Tabel 3. Hasil Simulasi dan Hitung Volume Air Yang Dibutuhkan

\begin{tabular}{crrr}
\hline Bentuk & $\begin{array}{c}\text { Volume } \\
\text { Ponton } \\
\left(\mathbf{m}^{\mathbf{3}}\right)\end{array}$ & $\begin{array}{c}\text { Volume Air } \\
\text { yang } \\
\text { Dibutuhkan } \\
(\mathbf{V})\end{array}$ & $\begin{array}{c}\text { Volume Air } \\
\text { yang } \\
\text { Dibutuhkan } \\
\text { Hitung } \\
\text { (Vhitung) }\end{array}$ \\
\hline Kubus & 0,1 & 0,03357 & 0,03507 \\
& 0,125 & 0,03898 & 0,04012 \\
Tabung & 0,15 & 0,04397 & 0,04312 \\
& 0,1 & 0,02622 & 0,00501 \\
Bola & 0,15 & 0,03423 & 0,02301 \\
& 0,1 & 0,03625 & 0,0268393 \\
& 0,125 & 0,042 & 0,0324633 \\
\hline Daris & 0,15 & 0,04759 & 0,0374633 \\
\hline
\end{tabular}

Dari tabel di atas menunjukkan tabel hasil simulasi dan perhitungan dari volume air yang dibutuhkan untuk menggerakkan turbin dalam satu periode. Hasil pada simulasi dan perhitungan menunjukkan kebutuhan air pada bola dengan volume $0,15 \mathrm{~m} 3$ lebih besar dibandingkan dengan bentuk dan ukuran ponton lainnya.

\section{KESIMPULAN DAN SARAN \\ Kesimpulan}

1. Ponton berbentuk bola dengan volume 0,15 $\mathrm{m}^{3}$ menghasilkan ketinggian air tertinggi yaitu 28,1575251 meter pada simulasi dan 16,23343796 meter dari perhitungan.

2. Ponton berbentuk tabung dengan volume 0,1 m3 menghasilkan ketinggian air terendah yaitu, 8,54754156010766 meter dari hasil simulasi dan 4,927847356 meter dari hasil perhitungan.

\section{Saran}

Untuk mendapatkan performa yang optimal disaran untuk menggunakan volume yang besar dan juga disarankan menggunkan ponton berbentuk bola.

\section{DAFTAR PUSTAKA}

Astuti, Lusia Tri \& P. Sunardi, Matematika. Jakarta:Swadaya Murni,CV,2009.

Giancoli, Fisika Jilid 1, Jakarta: Erlangga,2001.

Hutabarat, Sahala \& Stewart M. Evans, Pengantar Oseanografi. Jakarta: Penerbit Universitas Indonesia,1985

Jamrud Aminuddin, Dasar-Dasar Fisika Komputasi Menggunakan MATLAB, Yogyakarta: Gava Media, 2008.

Kementrian Energi Dan Sumber Daya Mineral Republik Indonesia. 2016. "Jurnal Energi Media Komunikasi Kementrian Energi Dan Sumber Daya Mineral Edisi 01." (http://www.esdm.go.id/, di unduh 09 februari 2017).

Rithaudin, Ahmad\& Tarmudi B, Matematika, Jakarta: PT Sarana Panca Karya Nusa, 2011. 